\title{
Pemphigus vulgaris
}

\author{
Vijayendranath Nayak, ${ }^{1}$ Raghavendra Kini, ${ }^{2}$ Prasanna Kumar Rao, ${ }^{2}$ Ujwala Shetty ${ }^{2}$
}

'Department of Oral Medicine and Radiology, Melaka Manipal Medical College, Bukit Baru, Melaka, Malaysia

${ }^{2}$ Department of Oral Medicine and Radilogy, AJ Institute of Dental Sciences, Mangalore, Karnataka, India

\section{Correspondence to}

Dr Vijayendranath Nayak; drnayakomr@gmail.com

Accepted 13 April 2020

\section{DESCRIPTION}

A 35-year-old female patient reported with a problem of bleeding and swollen gums in the lower front tooth region for 2 weeks associated with mild pain, which is intermittent and aggravates on consuming any type of food.

Intraoral examination revealed multiple ulcerations and erosions with crustations seen on right and left buccal mucosa, floor of the mouth and gingiva. Ulcers presented with the well-defined borders with yellowish slough with the areas of reddish erythema. Ulcers were tender on palpation and not attached to the underlying structures (figure $1 \mathrm{~A}, \mathrm{~B}$ ). Based on the clinical presentation, provisional diagnosis of pemphigus vulgaris was given. Incisional biopsy of gingiva was carried out and report revealed hyperplastic striae with squamous parakeratinised epithelium with underlying connective tissue stroma. Hyperbasilar clefting was seen with large eosinophilic acantholytic cells (Tzanck cells) with basophilic nucleus. Basement membrane was intact with connective tissue stroma, which was highly cellular in nature with proliferating blood vessels and fibrinous exudate (figure 2). Considering all the clinical and histopathological findings, a final diagnosis of pemphigus vulgaris was given.

Pemphigus vulgaris is the most common form of pemphigus, accounting for over $80 \%$ of cases. In most patients, it affects the oral mucosa and is sometimes difficult to diagnose when only mucosal involvement is present. ${ }^{1}$ Desquamative gingivitis is the most common manifestation of the disease when gingival is involved, as reported in our case. ${ }^{2}$

Treatment is usually targeted at controlling the severity and preventing relapses. Systemic corticosteroids remain the gold standard treatment for pemphigus. It is preferable to start with low doses of prednisolone $(0.5-1.5 \mathrm{mg} / \mathrm{kg} /$ day $)$ initially. If

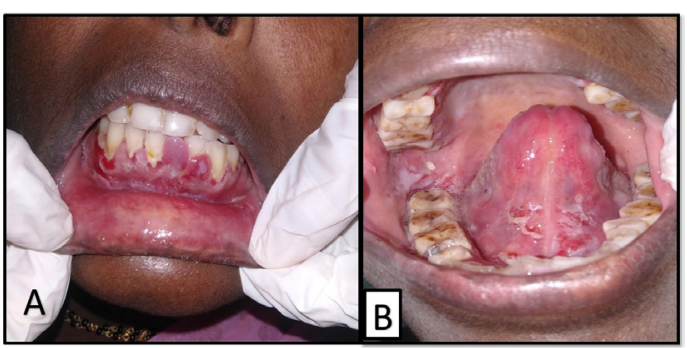

Figure 1 (A) Erosions seen on the gingiva, which is soft and edematous. (B) Erosions seen on the floor of the mouth and ventral aspect of tongue.

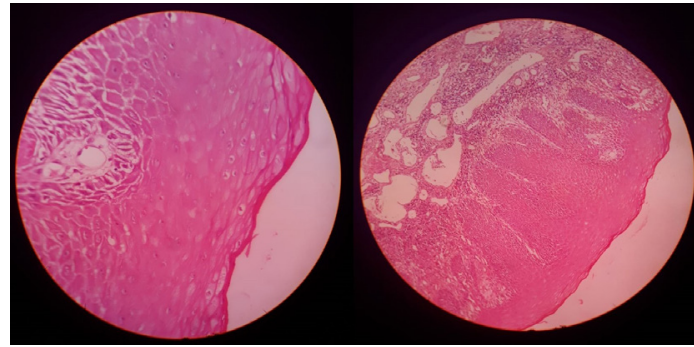

Figure 2 Histopathological sections revealing Tzanck cells.

there is no adequate response, then dose may be increased to up to $2.0-2.5 \mathrm{mg} / \mathrm{kg} /$ day. $^{3}$

Dental and periodontal follow-up is very necessary after attaining clinical remission, at least two to three times a year for the first year following diagnosis. ${ }^{4}$

\section{Learning points}

- Pemphigus vulgaris is the most common variant that affects the oral cavity.

- Oral lesions are the first manifestation of the disease in $50 \%-90 \%$ of the cases.

- The treatment should be organised by the dermatologist along with close cooperation of periodontologist for oral treatment.

Contributors VN contributed to conception and design, acquisition of data or analysis, interpretation of the data, drafting the article or revising it critically for important intellectual content, final approval of the version published and agreement to be accountable for the article and to ensure that all questions regarding the accuracy or integrity of the article are investigated and resolved. RK and PKR contributed to revising important intellectual content. US contributed in the final approval.

Funding The authors have not declared a specific grant for this research from any funding agency in the public, commercial or not-for-profit sectors.

Competing interests None declared.

Patient consent for publication Obtained.

Provenance and peer review Not commissioned; externally peer reviewed.

\section{REFERENCES}

1 Arpita R, Monica A, Venkatesh N, et al. Oral pemphigus vulgaris: case report. Ethiop J Health Sci 2015;25:367-72.

2 Scully C, Paes De Almeida 0, Porter SR, et al. Pemphigus vulgaris: the manifestations and long-term management of 55 patients with oral lesions. Br J Dermatol 1999;140:84-9.

3 Kala N, Manjeu J, Dominic N, et al. Oral pemphigus without skin lesions treated with pulse steroid therapy. J Indian Soc Periodontol 2018;22:551-4.

4 Mezzour M, Elharti K, Elwady W. Focus on oral pemphigus vulgaris's management Int. J Appl Dent Sci 2018;4:289-92. 
Images in...

Copyright 2020 BMJ Publishing Group. All rights reserved. For permission to reuse any of this content visit https://www.bmj.com/company/products-services/rights-and-licensing/permissions/

BMJ Case Report Fellows may re-use this article for personal use and teaching without any further permission.

Become a Fellow of BMJ Case Reports today and you can:

- Submit as many cases as you like

- Enjoy fast sympathetic peer review and rapid publication of accepted articles

Access all the published articles

Re-use any of the published material for personal use and teaching without further permission

Customer Service

If you have any further queries about your subscription, please contact our customer services team on +44 (0) 2071111105 or via email at support@bmj.com.

Visit casereports.bmj.com for more articles like this and to become a Fellow 